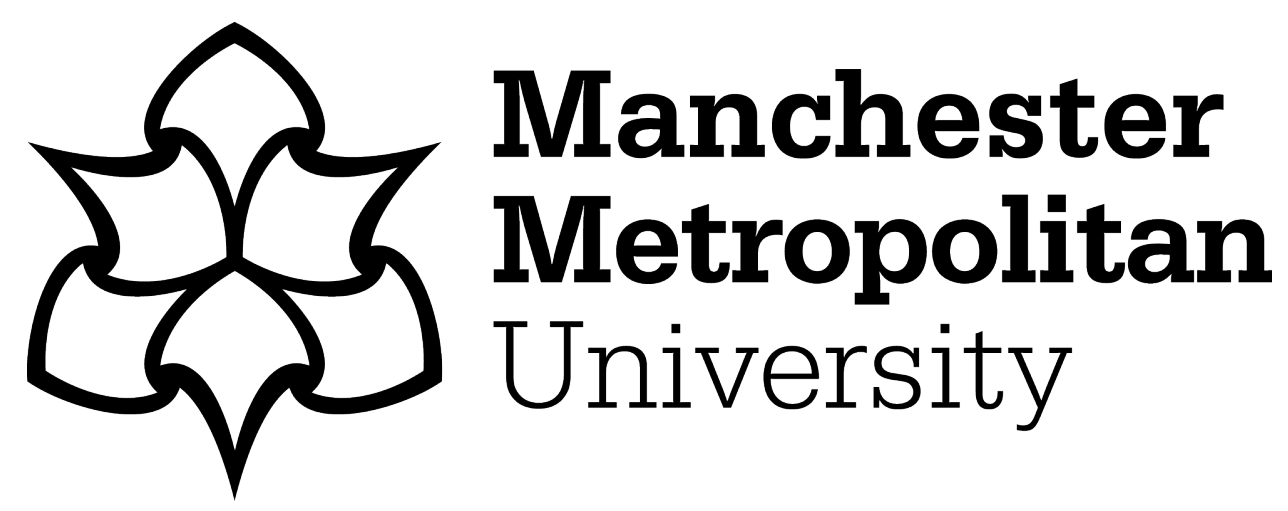

Pijetlovic, K ORCID logoORCID: https://orcid.org/0000-0002-9801-4827 (2013) Fundamental rights of athletes in the EU post-lisbon. In: Protecting Human Rights in the EU: Controversies and Challenges of the Charter of Fundamental Rights. Springer, pp. 161-186. ISBN 3642389015

Downloaded from: https://e-space.mmu.ac.uk/624314/

Version: Accepted Version

Publisher: Springer

DOI: https://doi.org/10.1007/978-3-642-38902-3_10

Please cite the published version 


\title{
FUNDAMENTAL RIGHTS OF ATHLETES IN THE EU POST-LISBON
}

\author{
Katarina Pijetlovic
}

In: "Protecting Human Rights in the EU: Controversies and Challenges of the Charter of Fundamental Rights" Springer (2013), pp 161-186.

\begin{abstract}
As a preliminary matter, this Chapter first addresses the issue of the Union's new competences in sport that entered into force as a result of Lisbon Treaty amendments and the question of whether the practice of sport itself can be considered a fundamental right. Thereafter, it is argued that the Chapter ought to be applicable to the rules and practices of the sport governing bodies due to their state-like competences and the scope of regulatory latitude. However, it is only in the context of Union's economic provisions, i.e., under the judicial test for regulatory rules in sport devised by the Court in Meca-Medina and the equivalent internal market objective justification framework, that the Charter may be utilized to supplement athletes' legal arguments. As such it provides a counterbalance to the Article 165(1) TFEU concept of the 'specificity of sport' that sporting federations rely on to justify their restrictive measures. A number of the sporting rules are examined along the lines of this framework, including beginning-of-season standard agreements (a.k.a. contracts of adhesion) the content of which the athletes have no opportunity to affect as the social dialogue in many European sports is still underdeveloped; fair trial issues in the system of distribution of sporting justice; and the rights to privacy and to rest involved in the anti-doping control.
\end{abstract}

\section{Introduction}

Whereas sport is not the first thing that springs to mind in the context of fundamental rights, the interaction between the two fields is a dynamic one. Sporting federations are monopolistic self-governing bodies possessing a degree and scope of regulatory latitude unmatched by any private entity in other industries. The boundaries of legal control of these entities have always presented a policy problem for both Member States' and the EU institutions. On the one hand, the right of sport to self-govern is widely acknowledged in the EU policy documents, on the other, the exercise of such high degree of autonomy has global impact and often results in breaches of law, including fundamental rights of sportspersons. In such events, athletes may turn to the internal dispute settling bodies established by the federations in charge of their sporting discipline. In the case of negative outcome they may appeal to the Court of Arbitration for Sport whose decisions are reviewable only on very limited basis by the Swiss Federal Tribunal. It is therefore of utmost importance that the principles of fair trial, now enshrined in Article 47 of the Charter of Fundamental Rights of the EU ('the Charter'), in the system of distribution of sporting justice are observed. As shall be illustrated, this is often not the case. For example, there is a serious failure to comply with the fair trial guarantees before some of the sports dispute settlement bodies in the prosecution of corruption offences, as well as with Article 49(3) of the Charter which provides for the proportionality of criminal penalties. The recourse to the ordinary courts is excluded by the standard consent agreements that athletes sign in the beginning of each season and which is the precondition for participation in the competitions. As the European social dialogue process in sports is still in its infancy, the athletes 
in many sporting disciplines have neither the opportunity and proper representation to negotiate the terms of such agreements, nor can they otherwise affect their content. Moreover, the provisions and the implementation of the World Anti-Doping Code (WADC) adopted by World Anti-Doping Agency (WADA) which is applicable virtually across all sporting disciplines entails a number of concerns regarding athletes' rights to privacy and the right to rest, i.e., Articles 7 and 31 of the Charter, respectively.

This chapter addresses the outlined issues and argues for the application of the Charter to the rules and practices of the sport governing bodies due to their monopolistic state-like competences as well as the scope of their regulatory authority. The sports related jurisprudence in the EU thus far revolved around the economic rights of athletes under the internal market and competition provisions. The key point made by this contribution is that the Charter can be used in the familiar analytical framework devised for the regulatory rules in sport under those provisions to support and supplement athletes' economic arguments and counterbalance the reliance on Article 165 TFEU concept of 'specificity of sport' by the governing bodies seeking to justify their restrictive measures. In order to illustrate the real-life issues, we will refer to the regulation of tennis, the most popular individual sport in the world.

\section{EU sports competences and institutional structures}

Since 1997 Directorate-General for Education and Culture of the European Commission includes the Sport Unit ${ }^{1}$ which is responsible for cooperation within the Commission and with other EU institutions on sport-related issues, cooperation and meetings with national and international sports institutions, organisations and federations. Following the entry into force of the Lisbon Treaty, the Ministers responsible for sport of the 27 EU Member States can now meet in the formal setting of the Council. ${ }^{2}$ In its role as interpreter of the EU law, the Court of Justice of the European Union (the Court) played a central role in interpretation of the existing economic provisions in the sporting context. ${ }^{3}$

Until the entry into force of the Lisbon Treaty on 1 December 2009, the EU did not have direct legislative competence to regulate sport. The traditional instruments were (and still are) therefore essential to protect the core objectives of the Union when the rules and activities of sporting bodies obstruct the functioning of internal market and distort competition. These in the first place include the TFEU rules on competition (Articles 101 and 102 TFEU), rules on freedom of movement for workers (Article 45-48 TFEU), self-employed (Article 49-55 TFEU) and freedom to provide services (Articles 56-62 TFEU).

Article 165(1) TFEU, included under the Title XII on Education, Vocational training Youth and Sport, states that ' $[\mathrm{t}] \mathrm{he}$ Union shall contribute to the promotion of European sporting issues, while taking account of the specific nature of sport, its structures based on voluntary activity

\footnotetext{
${ }^{1} \mathrm{http}: / /$ ec.europa.eu/sport/index_en.htm

2 For e.g., there was a meeting of EU Sports Directors in Genval on 16-17 September 2010. See http://ec.europa.eu/sport/consultation-cooperation/co-operation-with-the-member-states_en.htm

${ }^{3}$ See, for e.g., cases such as Case 36/74Walrave and Koch v. Union Cycliste Internationale and others [1974] ECR 1405; Case 13/76 Gaetano Donà v. Mario Mantero [1976] ECR 1333; Case C-415/93Union Royale Belge Sociétés de Football Association and others v. Bosman and others [1995] ECR I-4921; Joined Cases C-51/96 and C-191/97 Christelle Deliège v. Ligue francophone de judo et disciplines associées ASBL, Ligue belge de judo ASBL, Union européenne de judo and François Pacquée [2000] ECR I-2549; Case C-176/96 Jyri Lehtonen and Castors Canada Dry Namur-Braine ASBL v. Fédération royale belge des sociétés de basket-ball ASBL (FRBSB) [2000] ECR I-2681; and Case C-325/08 Olympique Lyonnais SASP v. Olivier Bernard and Newcastle United FC judgment of grand Chamber of the Court delivered on 16 March 2010; Case C-519/04 David Meca-Medina and Igor Majcen v. Commission [2006] ECR I-6991
} 
and its social and educational function' [emphasis added]. According to Article 165 (2) 'Union action shall be aimed at: [...] developing the European dimension in sport, by promoting fairness and openness in sporting competitions and cooperation between bodies responsible for sports, and by protecting the physical and moral integrity of sportsmen and sportswomen, especially the youngest sportsmen and sportswomen'. Unlike the primary law provisions on, for example, fundamental rights and environmental protection, Article 165 TFEU does not contain a horizontal clause.

Article 2(5) TFEU in combination with Article 6 TFEU gives Union a competence to carry out actions that support, coordinate or supplement the actions of the Member States in the area of sport and that do not entail harmonisation of the Member States' laws or regulations. However, the examination of the equivalent past prohibitions of harmonisation and their treatment by the Court ${ }^{4}$ suggests that harmonising measures can be taken as long as they are nominally based on another Treaty competence and convergence can be achieved in practice by using other legal basis to pass the harmonising legislation. ${ }^{5}$ This indicates the possibility for the fundamental rights of athletes to be protected via, for instance, legislation facilitating their free movement in their capacity as service providers or employed persons.

\section{Sport and fundamental rights}

Access to sport on a non-discriminatory basis is considered by some academics as an emerging human right. ${ }^{6}$ It has been recognised as such under Fundamental Principles of International Olympic Committee's Olympic Charter ${ }^{7}$ which states that ' $[t]$ he practice of sport is a human right. Every individual must have the possibility of practising sport, without discrimination of any kind [...]'. Article 13 of the UN Convention on the Elimination of Discrimination Against Women ${ }^{8}$, which has been signed by all EU Member States, lists the right to participate in sport on a non-discriminatory basis as one of the social rights. Article 1 of the UNESCO International Charter of Physical Education and Sport $(1978)^{9}$ provides that '[e]very human being has a fundamental right of access to physical education and sport, which are essential for the full development of his personality. The freedom to develop physical, intellectual and moral powers through physical education and sport must be guaranteed both within the educational system and in other aspects of social life.' Article 30 (5) of the UN Convention on the Rights of Persons with Disabilities ${ }^{10}$, of which both EU and its Member States are signatories, includes the obligation to take appropriate measures to ensure the rights of persons with disabilities to participate on an equal basis with others in sporting activities. Whether or not sport can be considered as a fundamental right still remains a controversial topic. However, an issue that is free of any controversy is that sport has given rise to numerous human rights concerns. Some of the most notorious examples involve human trafficking in particular of young football players from Africa to Europe ${ }^{11}$; negative impact of sporting mega-events (such as Olympic Games and FIFA World Cup) on housing of disadvantaged groups in the society and their displacement in order to build the necessary infrastructure ${ }^{12}$; and various discriminatory

\footnotetext{
${ }^{4}$ Such as in the fields of social policy, education, vocational training, culture, and public health

${ }^{5}$ See the European Parliament, Directorate-General for Internal Policies, Study on the Lisbon Treaty and EU Sports Policy (2010) p. 13

${ }^{6}$ See, for e.g., Brems and Lavrysen 2012, p. 228

${ }^{7} \mathrm{http}$ ://www.olympic.org/Documents/olympic_charter_en.pdf

${ }^{8} \mathrm{http}$ ://www.un.org/womenwatch/daw/cedaw/text/econvention.htm

${ }^{9} \mathrm{http}$ //unesdoc.unesco.org/images/0021/002164/216489E.pdf

${ }^{10} \mathrm{http}$ ://www.un.org/disabilities/convention/conventionfull.shtml

${ }^{11}$ See, for e.g., Backe Madsen and Johansson 2008

${ }^{12}$ See, for e.g., Morel 2012, p. 229-259
} 
practices such as prohibition on women to compete in certain sporting disciplines ${ }^{13}$, and treatment of trans-genders and homosexuals ${ }^{14}$. The list goes on.

There has never been the case before the Court and the Commission dealing with fundamental rights of athletes. Similarly, the topic is not very conspicuous among EU sports law academics and there are no academic texts available on the Charter in the sporting context. There is no available study in the EU in the field of human rights and sport to date. The Commission's Strategy for Equality between Women and Men 2010-2015 is set out inter alia to encourage the mainstreaming of gender issues into sport-related activities. ${ }^{15}$ The statistics suggest that the number of women in leadership positions in sport is alarmingly low. In its research on racism, discrimination and exclusion in sport, the EU Agency for Fundamental Rights found that that despite significant progress made in past years, incidences of racism and ethnic discrimination affect sport at professional as well as at amateur level. ${ }^{16}$

Despite the inadequate efforts at the EU policy level, it must be emphasised that the main responsibility for organization and promotion of sport, as well as for any sporting rule and practice giving rise to violation of fundamental rights, remains exclusively with the sport governing bodies. They possess a high degree of discretion in the performance of their central roles and enjoy monopolistic position regarding regulation and organization of their respective disciplines, as shall be explained next.

\section{Sport governing bodies as addresses under the Charter}

According to Article 51 of the Charter the circle of addresses includes the institutions, offices and agencies of the Union with due regard to the principle of the subsidiarity, and Member States when they are implementing EU law. The provisions of the Charter do not extend the field of application of Union law and therefore a party cannot successfully invoke its provisions where the measure or action being challenged falls outwith the scope of Union law. In addition, the Charter does not have direct horizontal effect and is formally addressed to the actions of public authorities. ${ }^{17}$

In contrast to the rules and practices that can be attributed to public authorities, sporting rules and practices emanate from actions of private entities. International sports associations are normally registered in the commercial register in accordance with the law of the country of incorporation. However, regardless of such formal status, there is perhaps no other economic sector in which private bodies have the same scope of regulatory latitude as in sports sector, ${ }^{18}$ and within which they constructed what legal anthropologists would refer to as a semiautonomous social filed. ${ }^{19}$ Sporting authorities rely on commercial sponsorship and sales of broadcasting rights to sporting events rather than state funding and thus have a high degree of

\footnotetext{
${ }^{13}$ See, for e.g., the speech by Annette Hofmann at Play The Game conference in Cologne 'Women Challenge the IOC in Court: The Case of Ski Jumping' 5 October 2011, and BBC News 'Women Fight Olympic Ski Jump Ban ' 21 April 2009

${ }^{14}$ See the speeches at Parallel Session on Transgender Challenges at Play the Game conference in Cologne, 5 October 2011, and P. Griffin 'Inclusion of Transgender Athletes on Sport Teams' available at http://www.transgenderlaw.org/resources/Griffinarticle.pdf

${ }^{15}$ Communication from the Commission to the European Parliament, the Council, the European Economic and Social Committee and the Committee of the Regions of 21 September 2010 - Strategy for equality between women and men 2010-2015 [COM(2010) 491, final

${ }^{16}$ European Union Agency for Fundamental Rights 'Racism, ethnic discrimination and exclusion of migrants and minorities in sport: a comparative overview of the situation in the European Union', October 2010. Available at http://fra.europa.eu/sites/default/files/fra_uploads/1207-Report-racism-sport_EN.pdf

${ }^{17}$ For indirect horizontal effect of the Charter see De Mol 2012, pp. 280-303; Safjan and Miklaszewicz 2010, pp. 475-486; and Papadopoulous 2011, pp. 437-447

${ }^{18}$ Para. 3.7. of the J.L. Arnaut, Independent European Sport Review (2006)

${ }^{19}$ See for e.g., Greenfield and Osborn 2006, p. 171
} 
financial autonomy. In terms of political autonomy, many Member States have expressly delegated public authority to their national sport bodies. ${ }^{20}$

In addition, some sporting bodies are powerful participants in the global affairs and their influence should not be underestimated: for example, Fédération Internationale de Football Association (FIFA) has direct contacts with many heads of State from its Swiss headquarters, while the International Olympic Committee (IOC) has been granted the observer status at the United Nations. Nevertheless, the autonomy of these bodies is not unlimited and the sporting industry has relatively recently in the history undergone the process of juridification. ${ }^{21}$ In its 2007 White Paper on Sport the European Commission emphasised that 'most challenges can be addressed through self-regulation respectful of good governance principles, provided that EU law is respected'. ${ }^{22}$ Also in various other EU sports policy documents, the right to selfgovern is conditional upon respect for EU law. ${ }^{23}$ Although the autonomy was initially selfproclaimed, subsequently it became a matter of express or implicit delegation of competence by public to private bodies to regulate themselves within the confines of the law. In terms of their substantive powers, the true legal status of sport governing bodies can be found on the equilibrium between private and public authorities.

Furthermore, a classic European sport model is based on a pyramid structure where only one federation per country and per discipline can be a member of the European and global governing body that are at the apex of the pyramid. ${ }^{24}$ The 'one-federation-per-sport' structure reveals the apparent monopolistic position of the governing bodies. They pass the rules and regulations specifying the procedures for prosecuting various sporting offenses and imposing disciplinary sanctions which in turn affect the athlete's livelihoods and sometimes permanently terminate their careers; they determine the athlete selection criteria for certain competitions; and they rule every other aspect of their discipline claiming unfettered competences relating to doping, corruption, exception from normal labour laws, etc. The impact that these regulations have on the sportspersons is no different than the impact of formal laws passed by the states. In addition, they are far reaching in their scope as, when passed by the international federations, they apply globally to all the athletes and regulate in a collective manner every aspect of their professional and often some aspects of their private lives. Because international sporting federations possess state-like competences whose regulatory effect is equivalent to those of state action the question of the accountability for violations of law, fundamental rights in particular, is a pressing one. ${ }^{25}$

It is submitted that sports governing bodies, due to their specific nature, global influence and vast regulatory competence, ought to be considered as addressees under the Charter. This proposition is assisted by two distinct facts: first, the Court normally applies functional rather than formalistic approach it its teleological interpretation of the provisions of EU law, and second, the public/private divide has not been very pronounced (if at all) when it comes to treating sporting organisations under the EU law.

\footnotetext{
${ }^{20}$ Germany is the extreme example as national sports organisations enjoy a very high degree of autonomy, the federal and Länder governments having delegated policy making in the field of sport to them.

${ }^{21}$ A term used to describe the process by which sport leaves the safe zone of internal self-regulation and becomes a subject to ordinary laws. Under this process 'what were intrinsically social relationships between humans within a 'social field' become imbued with legal values and are understood as constituting legal relationships - thus social norms become legal norms.'. See Gardiner et al., 2005, pp. 84-88

${ }^{22}$ European Commission White Paper on Sport, COM(2007) 391 final, para. 4 [emphasis added].

${ }^{23}$ Notably in Communication from the Commission to the European Parliament, the Council, the European Economic and Social Committee, and the Committee of the Regions 'Developing the European Dimension in Sport' COM(2011) 12 final, 18. 1. 2011.

${ }^{24}$ European Model of Sport, Consultation Document of DG X, European Commission.

${ }^{25}$ Brems and Lavrysen 2012, p. 227
} 
Article 6 TEU accords the value of primary EU law to the Charter which puts it on equal footing with the Treaties. It is exactly in the sporting cases that involved questions on the application of internal market provisions of the TFEU, expressis verbis addressed to the Member States, that the Court extended the protection on fundamental economic rights of internal market to cover private bodies such as sporting federations. Namely, in 1974 Walrave judgment the Court specified that the prohibition of discrimination enshrined in those provisions does not apply only to action of public authorities but also to 'rules of any other nature aimed at regulating in a collective manner gainful employment and the provision of services' ${ }^{26}$ As the justification for this approach it considered that the fundamental objectives of the Union (related to freedom of movement in casu) would be frustrated by obstacles resulting from the exercise, by associations or organisations not governed by pubic law, of their legal autonomy. ${ }^{27}$ The approach of giving direct horizontal effect to free movement of persons has been confirmed in the subsequent sports case-law, such as Bosman, Deliège, and Lehtonen, ${ }^{28}$ and it became clear that sporting federations are addresses under the internal market provisions which are otherwise expressly directed at actions of the Member States. Furthermore, the non-sporting Viking judgment implies that provisions of the TFEU are capable of horizontal effect in cases where collective action of individuals produces regulatory effects similar to those resulting from State action. ${ }^{29}$ The same judgment specified that 'the fact that certain provisions of the Treaty are formally addressed to the Member States does not prevent rights from being conferred at the same time on any individual who has an interest in compliance with the obligations thus laid down'. ${ }^{30}$ Along these lines of logic, and due to the equivalent legal status of the Charter with the primary Union law, the exercise of legal autonomy of organisations that do not formally fall under the scope of public law and whose actions therefore cannot be attributed to Member State, could diminish the protection of human rights (as further detailed in the Charter) the Union is founded on. ${ }^{31}$ Combined with the specific nature and status of sport governing bodies and the scope of their regulatory influence, that fact should provide a sufficient trigger for the application of the Charter in such (quasi-)vertical situations and support arguments in favour of holding sporting bodies accountable for the breaches of the EU's bill of rights. ${ }^{32}$ This approach was implied by the EU Expert Group on Anti-Doping set up by the Council of the EU that considered certain aspects of the World Anti-Doping Code in contravention with the Charter. ${ }^{33}$

\section{The concept of 'specificity of sport' as a restriction on the fundamental rights of athletes}

\footnotetext{
${ }^{26}$ Para 17. In Case 36/74Walrave [2012] one of the questions related to the horizontal direct effect of the TFEU Articles 18, 45 and 56, as the respondent in the case, Union Cycliste International, was not a body governed by public law but a private sporting organisation.

${ }^{27}$ Ibid. para 18.

${ }^{28}$ Case C-415/93Bosman [1995]; Joined Cases C-51/96 and C-191/97 Deliège [2000]; Case C-176/96 Lehtonen [2000].

${ }^{29}$ Case C-438/05 Viking Line judgment of 11 December 2007, para 79; Case C-341/05 Laval judgment of 18 December 2007.

${ }^{30}$ Ibid., para 58.

${ }^{31}$ See Art. 2 TEU.

${ }^{32}$ Alternatively, nothing in the Charter indicates that indirect horizontal effect of its provisions is precluded. This is supported by the Court's jurisprudence in cases like C-144/04 Mangold v Helm [2005] E.C.R. I-09981 and Case C-555/07 Kücükdeveci [2010], judgment of 19 January 2010. However, even in the context of indirect horizontal effect it should not be forgotten that we are not talking about classic private operators to which many policy questions, such as whether the obligation to comply with the fundamental freedoms would be excessively burdensome, apply.

${ }^{33}$ For details, see the discussion below in the subparagraph on anti-doping control.
} 
It is generally accepted that there should be no difference in protection of fundamental rights of athletes and any other economically active person in the EU. This in turn also means that the rights of athletes are not unconditional. In addition to the rights sometimes being restricted due to the conflict with other rights and freedoms, in the sporting context the rights of athletes are further conditioned by the concept of 'specificity of sport'. The concept has been established, recognised, and taken into account in the jurisprudence of the Court ${ }^{34}$ and the Commission practice. Following Lisbon Treaty amendments it was included in Article 165(1) TFEU imposing a positive constitutional obligation on the Union to 'contribute to the promotion of European sporting issues, while taking account of the specific nature of sport [...]'. It is utilized to justify practices in breach of EU economic freedoms that would not be allowed in any other industry.

European Commission explained that in order to assess the compatibility of sporting rules with any provisions of EU law, it considers the legitimacy of the objectives pursued by the rules, whether any restrictive effects of those rules are inherent in the pursuit of the objectives and whether they are proportionate to them. ${ }^{35}$ Objectives specific to the sporting community accepted by the Court as legitimate so far were, for example, ensuring regularity of competitions (players can effectively be transferred to another club only during short window in-between seasons which limits their ability to find work for most of the year ${ }^{36}$; maintaining the balance between clubs by preserving a certain degree of equality and uncertainty as to results; encouraging the recruitment and training of young players (on the first professional transfer of a football player the club that trained him must get financial compensation thus limiting player's attractiveness for the clubs that want to sign him) ${ }^{37}$; and combating doping in order for competitive sport to be conducted fairly including the need to safeguard equal chances for athletes, athletes' health, the integrity and objectivity of competitive sport and ethical values in sport $^{38}$. White Paper on Sport addressed some of the general aspects and divided the approach to the concept into the specificity of the sport structure (including notably the autonomy and diversity of sport organisations, a pyramid structure of competitions from grassroots to elite level and organised solidarity mechanisms between the different levels and operators, the organisation of sport on a national basis, and the principle of a single federation per sport), and the specificity of sporting activities and of sporting rules (such as separate competitions for men and women, limitations on the number of participants in competitions, or the need to ensure uncertainty concerning outcomes and to preserve a competitive balance between clubs taking part in the same competitions). ${ }^{39}$ Commission Staff Working Document on Sport and Free Movement of January 2011 states that 'the specificity of sport cannot be used as an excuse for making a general exception to the application of free movement rules to sports activities. Exceptions from the EU's fundamental principles must be limited and based on specific circumstances' ${ }^{40}$ This places emphasis on case-by-case approach.

The concept of specificity of sport can be expected to continue playing the same restrictive role on the scope of the rights guaranteed under the Charter as it did in relation to economic freedoms and provide a unique set of justifications that shield the rules and practices of the sport governing bodies from falling foul of the applicable EU law. Whereas there exists no constitutional requirement to take into consideration Article 165 TFEU in the Union's

\footnotetext{
${ }^{34}$ See for e.g., Case C-325/08 Bernard judgment of grand Chamber of the Court delivered on 16 March 2010.

${ }^{35}$ Commission Communication on Developing European Dimension in Sport (2011), para. 4.2.

${ }^{36}$ Case C-176/96 Lehtonen [2000].

${ }^{37}$ Case C-415/93 Bosman and Case C-325/08 Bernard.

${ }^{38}$ Case 519/04 Meca-Medina.

${ }^{39}$ White Paper on Sport, para. 4.1.

${ }^{40}$ Commission Staff Working Document 'Sport and free Movement' Brussels SEC(2011) 66/2 - Accompanying document to the Commission Communication on Developing European Dimension in Sport (2011), p. 7.
} 
legislative action, the Court's treatment of that provision in Bernard supports the view that 'the new sports competence may have given further weight to sports-related arguments' and that the concept of specificity of sport gained additional significance. ${ }^{41}$

However, as will be explained next, both the specificity of sport and Charter arguments can take place only within the scope of the EU economic provisions. As such, the Charter may be utilized as to support the legal arguments of athletes in the framework of their economic rights and thus provide a counterbalance to the concept of specificity of sport.

\section{Charter as a supplementary avenue of legal argument and counterbalance against specificity of sport}

The requirement to respect fundamental rights defined in the context of the Union is only binding within the scope of Union law ${ }^{42}$ and the Charter may not have the effect of extending the field of application of Union law beyond the powers of the Union as established in the Treaties. ${ }^{43}$

Thus far in the EU law, the difference between economic and non-economic sporting activities was crucial to establish the EU competence in the matter. In Walrave, the Court famously held that 'the practice of sport is subject to Community law only in so far as it constitutes economic activity $^{\text {'4 }}$. This jurisdictional threshold will therefore act as a trigger for bringing the sporting case under the scope of the Union law, and consequently for the application of the Charter. Furthermore, it is an established case-law that self-employed professional sportspersons constitute service providers within the meaning of Articles 56/57 and 'undertakings' for the purposes of 101 and 102 TFEU, that players employed by the sports clubs are 'workers' within the meaning of Article 45 TFEU, and that their activities can constitute economic activities which fall within the scope of those provisions. Purely amateur pursuit will not benefit from the economic provisions of the Treaty and will fall outwith the Union competence. These provisions conferring substantive rights onto their respective subjects of protection are directly effective and as such can be relied on before the national courts.

Furthermore, the Court held in Meca-Medina that '[i]f the sporting activity in question falls within the scope of the Treaty, the conditions for engaging in it are then subject to all the obligations which result from the various provisions of the Treaty. ${ }^{45}$ The conditions for engaging in the remunerated sport are set by the sport governing bodies. It was therefore confirmed in Meca-Medina that rules and practices of such bodies which govern economic activity of professional sportsperson must satisfy the requirements of TFEU provisions, in particular those provisions that seek to ensure free movement and unrestricted competition. The Court then set out a test for regulatory rules in sport holding that not every restriction on the freedom of action necessarily falls within the prohibition laid down in Article 101:

For the purposes of application of that provision to a particular case, account must first of all be taken of the overall context in which the decision of the association of undertakings was taken or produces its effects and, more specifically, of its objectives.

\footnotetext{
${ }^{41}$ See the European Parliament, Directorate-General for Internal Policies, Study on the Lisbon Treaty and EU Sports Policy (2010), and Pijetlovic 2010, pp. 858-869

${ }^{42}$ Case 5/88 Wachauf [1989] ECR 2609; Case C-260/89 ERT [1991] ECR I-2925; Case C-309/96 Annibaldi [1997] ECR I-7493

${ }^{43}$ See the Explanations relating to the Charter of Fundamental Rights (2007/C 303/02) available at http://eurlex.europa.eu/LexUriServ/LexUriServ.do?uri=OJ:C:2007:303:0017:0035:en:PDF

${ }^{44}$ Case 36/74Walrave and Koch [1974] ECR 1405, para. 4

${ }^{45}$ Case 519/04 Meca-Medina, para. 28
} 
It has then to be considered whether the consequential effects restrictive of competition are inherent in the pursuit of those objectives [...] and are proportionate to them. ${ }^{46}$

The same test for compatibility of the restrictive measures as spelled out by Kraus and Gebhard ${ }^{47}$ can be found in internal market area. ${ }^{48}$ It is in the framework of Meca-Medina test and equivalent test under objective justification framework for the rules in breach of internal market provisions that fundamental rights under the Charter can be used to support athletes' arguments. Simply put, in the legal disputes involving application of EU law, the Charter is for athletes what specificity of sport is for the governing bodies and it acts as a counterbalance to that concept.

\section{Hypothetical example: using Charter to support athletes' economic rights}

A French football player is disqualified by UEFA (the governing body for European football) from the Champions League (a pan-European football club competition) because he has a neck tattoo that says: 'Allah is great'. He may challenge the rules of UEFA under Article 45 TFEU that provide for freedom of movement of employed persons. He may claim that prohibition of participation in Champions League is a severe restriction on his professional opportunities and that no club would employ him if he cannot participate in that competition. UEFA may try to objectively justify its measure on the basis that displaying any religious symbols and slogans in sport would run counter to its robust implementation of policy of equality and fight against racism. The policy in itself is, no doubt, pursuing an objective worthy of protection under EU law. However, the suitability and proportionality of the rules would be hard for UEFA to prove: why it was not possible to have the same objective achieved with less restrictive means and why the disqualification of a player on that basis was even suitable and necessary for the achievement of the objective. UEFA might invoke specificity of sport in terms of football's enormous influence on masses and its social and educational function mentioned in Article 165(1) TFEU and claim that the successful implementation of their policy demands measures showing zero tolerance towards any religious slogans that can be interpreted by the masses as a sign of intolerance towards other religions. In demonstrating the unsuitability and disproportionality of the rules the football player will assert that disqualification is not capable of achieving the objective as the policy itself manifests religious intolerance and is in either case exceeding what is necessary to attain its aim. To support his arguments, he may claim violation of his rights under Article 10 of the Charter that provides for freedom of religion including freedom, either in public or in private, to manifest religion or belief. It would be more difficult for the Court to provide a sound reasoning for accepting as proportionate a rule that violates fundamental rights than it would be otherwise. The violation of fundamental rights will therefore play an opposing role in the balancing act to the specificity of sport and its different demands to those of other industries due to its immense social impact and educational role. It is in this manner that the Charter may be used in the interpretation of the Union's economic provisions in the sporting sector.

Were our hypothetical athlete self-employed, which is the case in individual sports, he could have brought an action against governing body under Article 56, 101 and 102 TFEU. The same test and the same arguments would apply.

With this analytical background in mind, what follows is the examination of some of the more prominent human rights issues in sport. First, however, we will look at the contractual arrangements that supply to the sporting bodies pacta sunt servanda argument as a rationale for the application to athletes of all the rules they adopt (along with the fundamental rights concerns

\footnotetext{
${ }^{46} \mathrm{Ibid}$., para. 42. [emphasis added] This test applies to Article 102 as well by virtue of the Court's decision in C250/92 DLG case, a precursor to C-309/99 Wouters and C-519/04 Meca-Medina in which this test was applied to both Articles 101 and 102.

${ }^{47}$ Case C-19/92 Kraus [1993] ECR I-1663 para. 32; and Case C-55/94 Gebhard [1995] ECR I-4165 para. 37.

${ }^{48} \mathrm{It}$ is of importance to mention that in the sports cases the Union's competition and free movement rules converge to a high extent and that, contrary to established case-law, both indirectly discriminatory and non-discriminatory measures as well as directly discriminatory measures benefit from open list of public policy justifications. At the same time, public policy objectives can be relied on in the framework of Article 101 and 102 TFEU under MecaMedina framework (although in competition law normally only economic justification under Article 101(3) TFEU can be used). While the EU competition rules are clearly addressed to private undertakings, internal market rules are addressed to Member States. Sports federations are a subject to both set of norms.
} 
they raise). This argument quickly reaches its limits under the conditions described in the following subsection.

\section{Contracts of adhesion and athlete representation: implications for Article 12 of the Charter}

The freedom of association was relied on by the UEFA in Bosman case to take the challenged UEFA rule out of the scope of Union law because, as the German government argued, the intervention by public authorities in the autonomy enjoyed by a sporting federation must be confined to what is strictly necessary. ${ }^{49}$ The Court responded that the right guaranteed by Article 11 of the ECHR and constitutional traditions of the Member States is one of the fundamental rights protected by the Community legal order. ${ }^{50}$ It then qualified this statement stipulating that the UEFA rules in question which acted as an obstacle to economic freedom under Article 45 TFEU could not be seen necessary to ensure enjoyment of that freedom by the sporting associations, by the clubs or by their players, nor could they be seen as inevitable result thereof. $^{51}$ This was a confirmation by the Court that neither fundamental rights nor the autonomy of the sporting federations are unlimited and will have to be assessed against requirements Union's economic freedoms guaranteed to individuals. The decision left open the possibility that fundamental rights may be relied on by the governing bodies themselves to justify the breach of Union's free movement rules when they can be seen as necessary and inevitable for the enjoyment of fundamental right relied on by the associations themselves, or by the clubs or players associated to them.

According to the Secretary General of EU Athletes, another important step in balancing athletes' fundamental rights against the specificity of sport is developing effective social dialogue. ${ }^{52}$ Moreover, Commission Communication on Developing European Dimension in Sport states that 'good governance in sport is a condition for the autonomy and self-regulation of sport organisations. ${ }^{53}$ One of the important aspects of good governance is the representation of all stakeholders in the transparent and democratic decision-making process. In Europe, unlike in the US ${ }^{54}$, the social dialogue and collective bargaining agreements in sports are still in their infancy. Since 2001, the Commission has been supporting projects for the consolidation of social dialogue in the sport sector globally and specifically in the football sector. ${ }^{55}$ Studies were conducted to identify the social partners ${ }^{56}$ and the labour-related themes and issues suitable to be dealt by means of social dialogue in professional football, ${ }^{57}$ but also in some other professional sports. ${ }^{58}$ Nevertheless, the representation and bargaining strength of athletes in

\footnotetext{
${ }^{49}$ Case C-415/93 Bosman [1995] ECR I-4921, para. 72.

${ }^{50}$ Ibid., para. 79.

${ }^{51}$ Ibid, para. 80 .

${ }^{52}$ Palmer 2011.

${ }^{53}$ Communication 'Developing the European Dimension in Sport', para. 4.1.

${ }^{54}$ For the US see Halgreen 2004.

${ }^{55}$ See list of projects in fn. 6, section 5.3 in Commission Staff Working Document, The EU and Sport: Background and Context, Accompanying Document to the White Paper on Sport, COM (2007) 391 final.

${ }^{56}$ See Promoting Social Dialogue in European Professional Football (Candidate EU Member States), Report for the European Commission, November 2004, and; Study on the Representativeness of the Social Partner Organisations in the Professional Football Player Sector, Report for the European Commission, Project No $\mathrm{VC} / 2004 / 0547$ (2006).

${ }^{57}$ See Study into the Identification of Themes and Issues which can be Dealt with in a Social Dialogue in the European Professional Football Sector, Report for the European Commission, May 2008. See also the press release in The International Sports Law Review 1-2 (2008), p 109

${ }^{58}$ Such as cycling. See Study into the Identification of Themes and Issues to be Dealt with in a Social Dialogue in the European Professional Cycling Sector, report for the European Commission (2009)
} 
most of the sports in Europe can be described as very weak, as creating conditions for social dialogue process that can produce collective bargaining agreements has not been the priority for most of the sport governing bodies. As the Grand Chamber of ECtHR held in Demir and Baykara on the basis of Article 11 ECHR, the right to conclude collective agreements is 'one of the principal means - even the foremost of such means - for trade unionist to protect their interests'. ${ }^{59}$ Article 12 of the Charter provides for the equivalent right on freedom of assembly and of association, that encompass the right of everyone to form and to join trade unions for the protection of his or her interests. With this background in mind, it is important to consider whether sport governing bodies have a positive obligation to create conditions in which the interests of athletes affiliated to them, as the potential social partners, are properly represented. ${ }^{60}$

The mandate of the sport governing bodies is multifaceted and includes both rights and responsibilities towards all levels and all aspects of their discipline. Democratic, representative and transparent process of decision making is among those responsibilities that are the part of principles of good governance, and in turn, a condition for their rights related to the exercise of regulatory autonomy. This conditionality has so far been only a slogan in policy and theory, while reality portrays quite a different picture.

An example from the tennis governance will serve to illustrate the problems associated with the lack of proper athlete representation in practice. Namely, men's professional is governed by the $\mathrm{ATP}^{61}$, an association which was initially established to represent the interests of professional players. Today ATP is run by the Board of Directors consisting of three tournament organiser representatives, three player representatives and a chairman who is Executive Chairman and President of the ATP. 'Player representatives' include a former tournament director, former executive and agent at IMG (a major sports sponsor, management and media company that owns many of the leading tennis tournaments), and one former tennis player who currently works as a tennis commentator. ${ }^{62}$ The ATP Player Council representing players has ten current professional players as their members while no person in the Player Council advises players on the legal issues. They can deliver advisory opinions to the Board of Directors, which has the power to accept or reject the Player Council's suggestions. Much like it transpires from its modest role, this body is generally regarded as having no power to influence any of the ATP decisions.

Further to this apparent flaw in the governance, a tennis player must sign the standard Consent and Agreement with ATP at the beginning of each season in order to participate in competitions. By the terms of the Agreement the player inter alia consents to abide by the ATP Official Rulebook and The Uniform Tennis Anti-Corruption Programme that are not a part of the Agreement, so the provisions on, for example, what constitutes violation of the rules or the standard of proof and sanctions in case of offense, do not show up on the face of the Agreement, but only in the subsections of the detailed regulations to which it refers. The Agreement is partly an arbitration agreement granting exclusive jurisdiction to Court of Arbitration for Sport (CAS) to review the disputes between a player and the ATP. ${ }^{63}$ It states that 'no claim, arbitration, lawsuit or litigation shall be brought in any other court or tribunal.' By the terms of the Agreement, decisions of CAS are final and non-reviewable. A manager of the Rules and Competition at the ATP reported that while players do receive the Agreement prior to the start

\footnotetext{
${ }^{59}$ Demir and Baykara v. Turkey [2008] ECHR 1345

${ }^{60}$ There are also implications for the rights set out in Articles 27 and 28 of the Charter on right of collective bargaining and action

${ }^{61}$ Association of Tennis Professionals

${ }^{62}$ See ATP official website http://www.atpworldtour.com/Corporate/Management.aspx

${ }^{63}$ In addition, Section I (1) of the Uniform Tennis Anti-Corruption Programme provides that any decision related to corruption offence may be appealed exclusively to CAS.
} 
of each season, the overwhelming majority does not sign it until they arrive to their first season tournament and are prompted by the ATP staff before their first match to sign it or be disqualified from the competition (i.e., be denied access to provision of their services) ${ }^{64}$ Hence, such contract of adhesion creates a 'take-it-or-leave-it' situation as players had no opportunity to affect its terms at any stage. ${ }^{65}$

In Cañas v ATP Tour the Swiss Federal Tribunal (the only body with jurisdiction to review CAS judgments, albeit on a limited basis) ruled on this matter and held that such waiver of appeal is void because the athletes' purported consent to such exclusion agreements does 'obviously not rest on a free will' and is therefore 'tainted ab ovo':

[E]xperience has shown that, by and large, athletes will often not have the bargaining power required and would therefore have to submit to the federation's requirements, whether they like it or not. Accordingly, any athlete wishing to participate in organised competition under the control of a sports federation whose rules provide for recourse to arbitration will not have any choice but to accept the arbitral clause, in particular by subscribing to the articles of association of the sports federation in question in which the arbitration clause was inserted[...]. ${ }^{66}$

By analogy to this judgment, and subject to the notion of severability, nothing that players 'agree' to via the agreement is valid and enforceable.

The extent and the type of rights that can be contractually waived is itself debatable. The ECtHR noted in Osmo Suovaniemi v. Finland that 'waiver may be permissible with regard to certain rights but not with regard to certain others. A distinction may have to be made even between different rights guaranteed by Article 6 $6{ }^{67}$ In general, for the waiver to be valid it has to be agreed knowingly and voluntarily, and no element of duress can be present. ${ }^{68}$ Add to this equation the manner of entry into agreement and the Cañas $v$ ATP Tour judgment of the Swiss Federal tribunal and more likely than not the athletes will be able to successfully argue that they are not bound by the rules that constitute waiver of any of their fundamental rights and other mandatory rules for the protection of the weaker party. Only a voluntary fundamental rights waiver negotiated in good faith between the two sides of the industry and in the full knowledge of the legal ramifications would necessitate different treatment, and depending on the nature of the rights in question, would stand a chance to survive a legal challenge.

The state of affairs just described carries, inter alia, implications for the rights guaranteed under Article 12 of the Charter. If the mandate of a monopolistic self-governing regulator includes ensuring the proper representation in their decision making, and if such representation does not exist, this certainly leads to assumption that they are effectively denying the right of athletes to protect their interests as envisaged by the Charter. Representation of all the stakeholders is also a pre-condition for their autonomy conditional upon the respect for law. This is not favourable state of affairs for the sporting bodies either as the collective agreements present a method that can keep legal disputes to a minimum and, in line with the Court's jurisprudence in the Albany,

\footnotetext{
${ }^{64}$ In her report only 2-5 players out of ca. 3000 return the signed forms before the season begins.

${ }^{65}$ Montmollin and Pentsov argue that 'the athlete who wants to participate competition does not have a choice and must accept the arbitration clause, in particular by adhering to the by-laws of the sports federation containing the arbitration clause, all the more when the athlete is a professional. Otherwise, he would be confronted by the following dilemma: agree to arbitration or practice his sport as an amateur'. See J. De Montmollin and D. Pentsov, Do Athletes Really Have the Right to a Fair Trial in "Non- Analytical Positive" Doping Cases?, 22(2) American Review of International Arbitration 239 (2011), p. 207.

${ }^{66}$ Cañas v ATP Tour and others 4P.172/2006 (2007) (Switz.), ATF 133 III 235, translated in 1 SWISS INT'L ARB.

L. REP. $65,84-85$

${ }^{67}$ Osmo Suovaniemi and others v. Finland, 23 February 2009, No. $31737 / 96$

${ }^{68}$ Landrove 2006, p.81
} 
Brentjens and Drijvende Bokken, agreements concluded in the context of collective bargaining between employee and employer trade unions that improve the working and employment conditions fall outside the scope of Article 101(1) TFEU, ${ }^{69}$ and would likely not be challenged on any other basis.

It is to be remembered, however, that the violation of the Charter rights by sporting bodies will be dependent on violation of athletes' economic rights and may be used to supplement their legal arguments under TFEU economic provisions. From the internal market and competition law perspective, the entry into compulsory agreements is the precondition for entry into the market for provision of professional tennis player services and access to the ATP's essential organising services that can be seen as constituting an analogous necessity for the operation on the market to the 'essential facilities'. Much like the access to essential facilities the access to the monopolised organising services should be provided on reasonable terms. It must be acknowledged that if the clauses in the standard agreements were favourable for the athletes and not in the breach of their economic freedoms there would be no basis in the EU law for the legal challenge to the manner of putting forth and the manner of acceptance of such clauses. The autonomy conditional upon respect for principles of good governance remains a policy slogan that has no discrete basis for challenge in EU law. The conditions stipulated in the unilaterally imposed standard clauses may, however, present an abuse of dominant position by the governing bodies under Article 102 TFEU, an illegal agreement under Article 101(1) TFEU, or a restriction on the free movement of athletes, in which case the avenue to challenge the unrepresentative and compulsory system that lead to the acceptance of the agreement is wide open. Within the Meca-Medina framework or equivalent internal market objective justification test, the arguments on violation of Article 12 of the Charter can be added to help illustrate the lack of inherency and/or disproportionality of the unrepresentative structures and the scheme that was at the inception of, and responsible for the breach of athletes' economic rights.

\section{Fair trial guarantees in the system of sporting justice}

Sports governing bodies have their regulatory and organisational rules spelled out in their statutes, charters, regulations, codes and other rulebooks and constitutions, as the case may be. As already clear, they take decisions that can have profound economic effects on many different actors in the world of sport, such as athletes and clubs. For the administration of the whole body of rules, regulations and decisions issued by sports organisations, referred to as the lex sportiva, the Olympic Movement established the Court of Arbitration for Sport (CAS) in 1984 as its highest arbitration body for resolving sport-related disputes. CAS has a sole jurisdiction to rule on the commercial issues in the disputes related to sport, and it acts as an appellate body of the last instance in disciplinary cases, most of which concern breach of anti-doping rules but also corruption offences by athletes. The CAS Panel decides the disputes according to the rules of law chosen by the parties or, in the absence of such a choice, according to lex fori (Swiss law). ${ }^{70}$ Hence, CAS jurisprudence itself has become one of the main sources of lex sportiva. The impact of their arbitral awards is similar to that of judicial bodies' decisions.

CAS arbitral awards are appealable only to Swiss Federal Tribunal and can be reviewed only on the grounds of procedural public policy guarantees under Article 190 (2) of Swiss Federal

\footnotetext{
${ }^{69}$ Case C-67/96 Albany International BV v. Stichting Bedrijfspensioenfonds Textielindustrie [1999] ECR I-5751, Cases C-115, 116 \& 117/97 Brentjens' Handelsonderneming BV v Stichting Bedrijfspensioenfonds voor de Handel in Bouwmaterialen [1999] ECR I-6025 and Case C-219/97 Drijvende Bokken [1999] ECR I-6121

${ }^{70}$ CAS Statutes, 2012 edition, Article R45. For more information on the Court of Arbitration for Sport see, for e.g., Blackshaw 2009, pp. 45-99
} 
Code on Private International Law, such as fair trial. ${ }^{71}$ In Lazutina case Swiss Federal Tribunal implied that fair trial guarantees must be respected before the CAS in its arbitration proceedings. ${ }^{72}$ Does it suffice that the Swiss Federal Tribunal has ex post facto power to consider whether the CAS respected procedural public policy guarantees, including fair trial guarantees, provided that one of the parties challenged the arbitral award on the basis of Article 190 (2) of Switzerland's Federal Code on Private International Law? This and a number of other pertinent questions related to minimum fair trial guarantees before CAS were examined by Černič who convincingly argued that Article 6 ECHR as developed by the ECtHR should also apply to CAS proceedings. ${ }^{73} \mathrm{He}$ noted that judicial review of respect for fundamental fair trial guarantees by the Swiss Federal Tribunal does not suffice to ensure the respect for fair trial guarantees before the CAS and it only takes place if the arbitral award is challenged before the Swiss Federal Tribunal. ${ }^{74}$ Therefore, the CAS should be responsible for safeguarding respect for fair trial guarantees in its proceedings.

Cernič identified the following problems related to the right to fair trial before the CAS: the appointment of qualified arbitrators and their later selection in individual cases is not very transparent; the time it takes to resolve procedures is several times longer than envisaged and thereby violates athlete's rights ${ }^{75}$; the publication of proceedings has not yet gained a foothold as a fundamental principle in sports arbitration procedures; and the standard of proof employed is too low.

With the purpose of illustrating the standard of proof issues in sport, we will continue with our tennis example in which the clauses in the compulsory standard agreements described supra in this chapter lead to the application and enforcement of Uniform Tennis Anti-Corruption Code (UTACP) that contains a number of articles not in conformity with the right to fair trial. ${ }^{76}$

According to Article G(3)(a) of the UTACP 'the standard of proof shall be whether the PTIO has established the commission of the alleged Corruption Offense by a preponderance of the evidence. [...]'. However, match-fixing is a criminal offense and standard of proof more appropriate to criminal offenses should be used to prove the charges of match-fixing. It is wellestablished by the case-law of the ECtHR that the notion of a 'criminal charge' is an autonomous concept which is a matter of ECHR law. ${ }^{77}$ The principles laid down by the ECtHR for identifying a criminal charge is known as the 'Engel criteria'. They are: the classification of the offence under national law, the nature of the offence, and the nature and severity of the potential penalty. ${ }^{78}$

\footnotetext{
${ }^{71}$ Article 190 (2) of Swiss Federal Code on Private International Law sets out procedural public policy guarantees and specifies that that an arbitral award can be challenged only 'if a sole arbitrator was designated irregularly or the arbitration tribunal was constituted irregularly; if the arbitration tribunal erroneously held that it had or did not have jurisdiction; if the arbitration tribunal ruled on matters beyond the claims submitted to it or if it failed to rule on one of the claims; if the equality of the parties or their right to be heard in an adversarial proceeding was not respected; and if the award is incompatible with Swiss public policy'. Fair trial guarantees in the Swiss legal order also form part of public policy

${ }^{72}$ A. and B. v. IOC and FIS (Lazutina), 4P.267-270/2002 (1st Civ. Ct., 27 May 2003)

${ }^{73}$ Černič 2012, pp. 259-283

${ }^{74}$ Ibid. 279

${ }^{75}$ The Contador case took one and a half years to resolve, which is three times longer than the time envisaged for appeal procedures

${ }^{76}$ The UTACP is mainly geared towards fight against match-fixing offences in which a person (often a tennis player, sometimes organised syndicates) attempts to affect the outcome of his/her own or other players' match by fixing the score in advance. This gives opportunity to earn hefty profits against the odds on the sports betting market. It is available at http://www.tennisintegrityunit.com/UTACP-2012.pdf

${ }^{77}$ Engel and Others v. Netherlands (1979-80) 1 E.H.R.R. 647

${ }^{78}$ Ibid.
} 
The UTACP itself deals with the match-fixing offences under the designation of 'corruption offences'. In the EU sports policy, match-fixing is a criminal offense. The study on matchfixing in sport by the Commission emphasised the need to fight this form of sports corruption through criminal legislation:

Resorting to criminal justice in the fight against match-fixing shows that sporting manipulation can be not only a 'simple' breach of sporting rules but also an offence against the public in a broader sense. ${ }^{79}$

In its Communication on Sport, the Commission similarly states that

$[\mathrm{m}]$ atch-fixing violates the ethics and integrity of sport. Whether related to influencing betting or to sporting objectives, it is a form of corruption and as such sanctioned by national criminal law. 80

Under the national laws of all the EU Member States, match-fixing constitutes a criminal offence and is dealt with under their criminal legislation. ${ }^{81}$ Member States apply criminal standard of proof to establish whether any such offence took place. The treatment of matchfixing under Member States' laws and Commission policy is illustrative of the disproportionality of the standard of proof under UTACP. Sanctions for the breach of the UTACP under that code may carry a life-time ban from participating in the professional tennis in any capacity even for the first attempt to fix a match, while fines are not just compensatory in nature but punitive exceeding the offenders' ability to pay ${ }^{82}$ (this in itself should be examined under Article 49(3) of the Charter requiring that severity of penalties must not be disproportionate to the criminal offence). In Member States' laws more serious cases of matchfixing may lead to imprisonment. The criminal standard of proof should therefore be the applicable standard for proving that corruption offence took place.

The rules that provide for lower standard of proof violate the athletes' right to fair trial under Article 6 of the ECHR and Article 47 of the Charter. Rules and practices adopted for the purpose of fighting match-fixing in sports should be designed so as to not deprive athletes of fundamental rights. If they go that far, it will be more difficult to prove their proportionality under the test framework developed in paragraph 42 of Meca-Medina and under the internal market objective justification framework. As regards the severity of the sanctions, it will be virtually impossible to prove their proportionality in the context of the economic argument if they are disproportionate under Article 49(3) of the Charter.

In the first instance disciplinary cases are usually dealt with at the level of the competent authorities of the sport in question by their internal quasi-judicial dispute settlement mechanisms. The conflation of prosecuting, investigative, and adjudicating functions in one body in the enforcement of the rules, which is often the case in sporting justice, appear problematic from the point of view of Article 47 of the Charter.

The first sentence of Article 6 (1) ECHR providing for a hearing before an independent and impartial tribunal applies to civil as well as to criminal proceedings. In order to establish under Article 6 of the ECHR whether a body can be considered 'independent', regard must be had, inter alia, to the manner of appointment of its members and their term of office, to the existence of guarantees against outside pressures and to the question whether the body presents an

\footnotetext{
79 'Match-fixing in sport: a mapping of the criminal law provisions in EU 27' (March 2012), pp. 15-16. Available at http://ec.europa.eu/sport/news/documents/study-sports-fraud-final-version_en.pdf.

${ }^{80}$ Commission Communication 'Developing the European Dimension in Sport' January 18, Brussels, COM(2011)

12 final, para. 4.5

81 'Match-fixing in sport: a mapping of the criminal law provisions in EU 27' (March 2012), pp. 15-16

${ }^{82}$ Decisions in Köllerer and Savic cases before the Anti-Corruption Hearing Officer are kept secret and not published but both players received a life-time ban and a fine of 100.000 and 85.000 USD respectively. Redacted CAS awards confirming the ban but lifting the fines are available at http://www.tas-cas.org/recent-decision
} 
appearance of independence. ${ }^{83}$ The rule against bias (nemo judex in sua causa) is a principle of natural justice and forms an indivisible part of the right to fair trial. In the legal systems of EU Member States, the rule against bias requires adjudicator to be free from any interest in the case - in the jurisprudence of the UK courts this can be financial which automatically disqualifies the adjudicator ${ }^{84}$, or where there is the likelihood of the appearance of bias ${ }^{85}$ (so there is no need for actual bias).

Tennis has its Anti-Corruption Hearing Officer (AHO) that acts as an adjudicator for the offenses of the UTACP. He is financed by the Tennis Integrity Unit (investigators) that is financed by the Governing Bodies of tennis, including ATP (prosecutors). Tennis Integrity Board, that appoints the AHO, was excluded from the list of Respondents before CAS proceedings because it was argued by the tennis Governing Bodies that it is simply a representative body of the other four respondents [i.e. the representative of the Governing Bodies]' ${ }^{86}$ Due to the structural links with the tennis Governing Bodies, appointment by Tennis Integrity Body, physical location in the same office and financial dependence on the tennis Governing Bodies, AHO does not appear as an independent and impartial body. Yet, its decisions have an effect of permanently excluding a tennis players from the market for provision of tennis player services, but also from coaching, managing, and any other economic activity that can give an access to the tournaments, and imposing fines that by far exceed players' ability to pay. ${ }^{87}$ This arrangement is yet another point for reform under the fair trial requirements as it can constitute an abuse of dominant position by the tennis Governing Bodies and a system of enforcement incompatible with economic provisions under TFEU due to the failure to meet the principle of proportionality.

In as far as the dispute concerns a restriction on the EU economic freedoms via the enforcement of the UTACP provision, an athlete that loses a case before the AHO and CAS may turn to the Commission to examine the sporting rule in question (not review the CAS decision per se), and thereafter appeal to the Court. In fact, any rule that involves alleged breach of the EU law by a sporting federation may be brought to the attention of the Commission that will act only if it considers that there is 'EU interest' in the case, ${ }^{88}$ which could prove a high burden to bear for the individual athletes. Conversely, national courts protect individual interests but they are very reluctant to examine the rules that affect the entire sporting discipline on a global level and any case brought before national courts that has an EU element will likely be referred to the Court on a preliminary reference procedure.

Finally, it remains to be mentioned that in its Communication on Sport

the Commission underscores the need for anti-doping rules and practices to comply with EU law in respecting fundamental rights and principles such as [...] the right to a fair trial and the presumption of innocence. Any limitation on the exercise of these

\footnotetext{
${ }^{83}$ See, inter alia, the ECHR judgment of 28 June 1984 Campbell and Fell v. United Kingdom Series A no. 80, pp. 39-40, para. 78

${ }^{84}$ Dimes $v$ Grand Junction Canal Co (1852) 3 HLC 759

${ }^{85}$ Locabail (UK) Ltd v Bayfield Properties [2000] 1 All ER 65

${ }^{86}$ Footnote omitted

${ }^{87}$ See David Savic and Daniel Köllerer cases before the AHO (but the decisions are secret but decisions (on appeal) by CAS provide a lot of insight) Appeal to CAS costs tens of thousands of Euros including lawyer and tribunal fees and this is amount that not many tennis players can afford, especially not after they have been imposed severe fines that only the richest of them can pay

${ }^{88}$ The General Court's judgment in T-24/90 Automec Srl v Commission, para 86 provides a test for the existence of the European Union interest in the case. Accordingly, in assessing such interest the Commission in particular looks at 1) the scope of the investigation required, 2) the probability of establishing the existence of the infringement, and 3) the significance of the infringement from the point of view of the internal market.
} 
rights and freedoms must be provided for by law and respect the essence of those rights and the principle of proportionality. ${ }^{89}$

There is no reason why the same considerations of fundamental rights and fair trial should not apply also to all other sporting rules and practices that restrict the athletes' economic freedoms.

\section{Anti-doping control: right to privacy and the right to rest}

World Anti-Doping Agency (WADA) was set up in 1999 at the initiative of the International Olympic Committee (IOC). It is a private and non-governmental agency financed by the IOC and the governments of the world. The agency is responsible for conducting scientific research, updating an annual list of prohibited substances, anti-doping education, development of antidoping capacities and monitoring of its World Anti-Doping Code (WADC) ${ }^{90}$. This code harmonises the rules and regulations governing anti-doping virtually across all sports and all countries. It has been incorporated in 2005 UNESCO International Convention against Doping in Sport - so far 145 governments ratified this convention and aligned their national policies on anti-doping. ${ }^{91}$

Testing of athletes can be done in-competition and out-of-competition. It is the out-ofcompetition testing and 'whereabouts' rule that has been a subject of most of the human rights controversy. Any professional athlete at any time (from 6:00 to 23:00) is a subject to potential visit from the agents who will gather his/her urine or blood sample (a procedure which is in itself so intrusive that it raises privacy concerns). However, a selected pool of elite players (for e.g., 50 first players in tennis) will additionally be a subject to 'whereabouts' reporting requirement which means that they have to, on a quarterly basis, a priori designate one hour slot each day between 6:00 and 23:00 at a specific location where they will be available to the anti-doping agents for testing. The testing visits are conducted without prior notice. It is simply expected from the athletes to be there where they said they would at the time they designated for every day of the year. The so-called ADAMS system may be used to change the information if the athlete's whereabouts change. If an athlete misses three tests in an 18-month period, he/she will be banned for at least a year. ${ }^{92}$

Article 31(2) of the Charter provides for the 'right to limitation of maximum working hours, to daily and weekly rest periods and to an annual period of paid leave'. Working Time Directive ${ }^{93}$ protects the right to rest in more details. According to its Article 3 Member States must ensure that workers have a minimum of 11 hours of uninterrupted rest in 24-hour period, and on the top of this, Article 5 provides for at least 24 hour of uninterrupted rest in a seven day period, but derogations can be justified for technical, organisational or work reasons or according to Article 17 'on account of the specific characteristics of the activities concerned'. Article 7 requires four weeks of paid annual leave. It is clear that WADA's 'whereabouts' rule goes against the requirements of Articles 3,5 and 7 of the Working Time Directive as well as Article $31(2)$ of the Charter. What will not be clear without a legal challenge is whether it may be a good candidate for the derogation and whether it is not possible to organize effective control while allowing athletes one day a week free from being included in the reporting obligations.

\footnotetext{
${ }^{89}$ Para. 2.1, [emphasis added]

${ }^{90} \mathrm{http} / /$ www.wada-ama.org/en/World-Anti-Doping-Program/Sports-and-Anti-Doping-Organizations/The-Code/

${ }^{91}$ For more on WADA see http://www.wada-ama.org

${ }^{92}$ For more information on the anti-doping programme see World Anti-Doping Code available at http://www.wada-ama.org/Documents/World_Anti-Doping_Program/WADP-The-Code/WADA_AntiDoping_CODE_2009_EN.pdf

${ }^{93}$ Directive 2003/88/EC of the European Parliament and of the Council of 4 November 2003 concerning certain aspects of the organisation of working time, OJ L 299 18.11.2003 p.9-19
} 
A panel of 27 EU Member State experts considered that many aspects of WADA 'whereabouts' rule contravene EU law, in particular its privacy laws. Another aspect of anti-doping control relates to ensuring the adequate level of personal data protection in accordance with the Directive on Data Protection ${ }^{94}$, and as nowadays also required by Article 8 of the Charter. In the light of proportionality principle the expert group of 27 invited WADA and anti-doping organisations to reassess the collection of whereabouts as conceived today, and more in general, the current retention period of processed data. WADA responded that these statements went beyond the mandate of expert group, saying they contain 'some regrettable factual errors and could potentially undermine the fight against doping'. ${ }^{95}$ Furthermore, Soek noted that the countries which ratified the UNESCO convention allowed private anti-doping organisations to invade the lives of their subjects anytime, anywhere and without notice, when in fact according to Article 8(2) ECHR violating the privacy of persons is only reserved to 'a public authority' and on a limited basis. ${ }^{96}$ This is yet another reason why the Charter should be applicable to the sporting organisations.

As noted by Černič, there are two conflicting values in a contemporary [doping control]: 'whether the prevention of doping may undermine the protection of athletes' fundamental human rights, and whether the protection of fundamental human rights may impede the suppression of doping, ${ }^{97}$ In the context of the EU objective justification framework, there is no doubt that objectives of anti-doping policy are legitimate. What will be at stake in the examination of the rules under the EU law is their proportionality. In fact, the most extreme example of the review of the proportionality of the sporting rules is the examination by the Commission and the EU Courts of the IOC anti-doping rules in Meca-Medina. ${ }^{98}$ The case involved two professional swimmers who were found to have breached the sport's anti-doping rules adopted by the IOC. They tested positive for nandrolone and were suspended for the period of four years by the Doping Panel of International Swimming Federation that implemented the rules for their discipline. ${ }^{99}$ Contesting the anti-doping rules the applicants asserted that they were in breach of Articles 101 and 102, and Article 56 on freedom to provide services:

[...] First of all, the fixing of the limit at $2 \mathrm{ng} / \mathrm{ml}$ is a concerted practice between the IOC and the 27 laboratories accredited by it. That limit is scientifically unfounded and can lead to the exclusion of innocent or merely negligent athletes. In the applicants' case, the excesses could have been the result of the consumption of a meal containing boar meat. Also, the IOC's adoption of a mechanism of strict liability and the establishment of tribunals responsible for the settlement of sports disputes by arbitration (the CAS and the ICAS) which are insufficiently independent of the IOC strengthens the anti-competitive nature of that limit. [....$^{100}$

\footnotetext{
${ }^{94}$ Directive 95/46/EC of the European Parliament and of the Council of 24 October 1995 on the protection of individuals with regard to the processing of personal data and on the free movement of such data, OJL 281 , 23.11.1995 p. 31-50

${ }^{95}$ The Guardian: 'EU puts WADA whereabouts rule in doubt' 21 April 2009

${ }^{96}$ Soek 2008, p. 100

97 Černič 2012, p.261

${ }^{98}$ Case C-519/04 Meca-Medina [2006] ECR I-6991

${ }^{99}$ The appeal against the suspension was first launched before the CAS which confirmed the decision of the doping panel but later when scientific experiments showed that nandrolone's metabolites can be produced endogenously by the human body at a level which may exceed the accepted limit when certain foods have been consumed, they reduced the sanctions to two years. In 2001, however, the applicants launched the complaint with the Commission whose decision they appealed to the General Court and finally the decision of the General Court was brought before the Court

${ }^{100}$ C-519/04 Meca-Medina, paras. 16-17
} 
The swimmers raised their claim under both, freedom to provide services and competition provisions of the Treaty. In addition to the test in paragraph 42 of that case cited above in this Chapter, the Court also acknowledged in paragraph 48 that

the penal nature of the anti-doping rules [...] and the magnitude of the penalties applicable if they are breached are capable of producing adverse effects on competition because they could, if penalties were ultimately to prove unjustified, result in an athlete's unwarranted exclusion from sporting events, and thus in impairment of the conditions under which the activity at issue is engaged in. It follows that, in order not to be covered by the prohibition laid down in Article [101 TFEU], the restrictions thus imposed by those rules must be limited to what is necessary to ensure the proper conduct of competitive sport[...].Rules of that kind could indeed prove excessive by virtue of, first, the conditions laid down for establishing the dividing line between circumstances which amount to doping in respect of which penalties may be imposed and those which do not, and second, the severity of those penalties.

Judgment in Meca-Medina, paragraphs 42 and 48 in particular, are generally applicable to all regulatory rules in sport and any aspect of anti-doping policy may be tested against these legal parameters. In that judgments the objectives of anti-doping control accepted by the Court as legitimate were the need to safeguard equal chances for athletes, athletes' health, the integrity and objectivity of competitive sport and ethical values in sport. After the Treaty of Lisbon amendments the sporting organisations may more readily rely on the concept of specificity of sport, taking into consideration of which was converted into constitutional requirement, to justify intrusion into athletes' fundamental rights. Athletes on the other hand will point out to the rights outlined under the Charter and the conflict of different values will take place within the objective justification framework of the two sets of TFEU economic provisions.

After the insertion of sport in Article 165 TFEU, the Council of the EU has become a pro-active player in relation to doping-related discussions at EU level. An EU Expert Group on AntiDoping was set up under European Union Work Plan for Sport for 2011-2014. It prepared the first EU contribution to the revision of the WADC, which was submitted by the Danish EU Presidency to WADA in March 2012. The following observations were made:

Although the prevention of doping constitutes a legitimate goal, the goal-driven provisions on RTPs and whereabouts regrettably do not set any limits to their application as no notion of proportionality can be found in these prescriptions. This sets them into conflict with applicable EU laws such as Article 52 (1) of the EU Charter of Fundamental Rights and Article 6 (1) (c) of the Directive 95/46/EC that render the processing of personal data under the requirement of necessity and proportionality to the legitimate goals pursued. ${ }^{101}$

The Council has extended the mandate of the Expert Group on Anti-Doping tasking it with the revision of the World Anti-Doping Code until its end in late 2013.

The contributions made by the Expert Group represent a non-binding opinion, but it will take a legal challenge before the EU Courts to confirm the legality under EU law of any of the controversial aspects related to the WADA's anti-doping programme.

\section{Concluding remarks}

In EU law, individual athlete's interests are safeguarded by the free movement and free competition principles spelled out in the TFEU economic provisions whereas the protection of sport federations' interests rest on the objective justification framework under those provisions. Within the scope of those opposing ends lies the heart of the conflict between athletes'

\footnotetext{
${ }^{101}$ Council of the European Union, EU contribution to the revision of the World Anti-Doping Code, 13516/12
} SPORT 47 DOPAGE 13 SAN 193 JAI 606 DATAPROTECT 104, Brussels 26 September 2012, para. 2.1.3. 
fundamental rights enshrined under the Charter and sporting autonomy as represented by the concept of 'specificity of sport' in Article 165(1) TFEU.

Any sporting rule can be challenged under the EU law as long as it has effect on the economic activity. Sporting activity which constitutes such economic activity thus falls within the scope of the TFEU and the conditions for engaging in it as laid down by the governing bodies are subject to all the obligations which result from the various TFEU provisions.

Governing bodies often impose the terms of contracts of adhesion, which cannot be negotiated, and are the first such condition for engaging in the economic sporting activity. More often than not these one-page standard contracts lead to the application of the number of detailed rulebooks and regulations which include clauses constituting a waiver of basic fundamental rights, such as the right to fair trial.

Principles of fair trial as a condition sine qua non for the protection of fundamental rights of athletes should be possible to depart from only partly and only in circumstances which involve a waiver in the full knowledge and on the basis of good faith negotiations and representation of both sides of the industry. Sports governing bodies have a positive duty to ensure that such social dialogue takes place, as their autonomy depends on the respect for the principles of good governance.

Whereas doping and match-fixing strike at the core of sport and fighting against these forms of corruption remains one of the centrally important issues in preserving the integrity of sport, it should not be overlooked that protecting the economic rights of athletes from adoption and enforcement of disproportionate anti-corruption and anti-doping rules by the sport governing bodies is equally important. The breaches of athletes' rights cannot be adequately addressed at the national court level as any national court is likely to refuse a jurisdiction over the cases that involve interfering with the regulations of the international sporting bodies, or be very reluctant to rule against the sporting regulations having global impact. Thus, the increased Commission diligence in its role as a guardian of the TFEU in pursuing the rules and practices that go beyond what is necessary for the attainment of the legitimate sporting goals appears indispensable.

\section{References}

- Backe Madsen L and Johansson J M (2008) Den Forsvunne Diamanten (The Lost Diamond). Tiden Norsk Forlag, Norway

- Blackshaw I (2009) Sport, Mediation and Arbitration. T.M.C. Asser Press, The Netherlands

- Brems E and Lavrysen L, editorial (2012) Human Rights \& International Legal Discourse. Human Rights and Sport - Special Issue, 226-228

- Černič J L (2012) Fair Trial Guarantees Before the Court of Arbitration for Sport. Human Rights \& International Legal Discourse. Human Rights and Sport - Special Issue, 259-283

- De Mol M (2012) Dominguez: A Deafening Silence. European Constitutional Law Review 8: 280-303

- Gardiner S et al. (2005) Sports Law, $3^{\text {rd }}$ ed. Cavendish Publishing, UK

- Greenfield S and Osborn G, eds. (2004) Readings in Law and Popular Culture. Routlegde, UK

- Halgreen L (2004) European Sports Law - A Comparative Analyses of the European and American Models of Sport. Forlaget Thomson, Copenhagen

- Landrove J C (2006) European Convention on Human Rights Impact on Consensual Arbitration. In: Besson, Hottelier, and Werro (eds). Human Rights at the Center. Basel, 73-101 
- Morel M (2012) Displaced in the Name of Sports: Human Rights Law Comes to the Rescue. Human Rights \& International Legal Discourse. Human Rights and Sport - Special Issue, pp. 229-258

- Palmer W (2011) Balancing Athletes' Fundamental Rights Against Specific Nature of Sport. Sport and Citizenship. Special issue - European Social Dialogue in Sport 15

- Pijetlovic K (2010) Another Classic of EU Sports Jurisprudence: Legal Implications of Olympique Lyonnais SASP v. Olivier Bernard and Newcastle UFC (C-325/08). European Law Review 35: 858-869

- Safjan M and Miklaszewicz P (2008) Horisontal Effect of the General Principles of EU Law in the Sphere of Private Law. European Review of Private Law 18: 475-486

- Soek J (2008) Is the Professional Athlete's Right to Privacy being Tacitly Ignored?. International Sports Law Journal 1-2: 100

- Papadopoulous T (2011) Criticizing the Horisontal Direct Effect of the EU General Principle of Equality. European Human Rights Law Review 4: 437-447 